\title{
Furtado e a educação pela pedra, entranhada
}

\section{Luciano Albino}

Universidade Estadual da Paraíba, Brasil

(D) https://orcid.org/0000-0002-4614-3715

lucianoalbino@yahoo.com.br

Eu venho de um mundo que me parecia catastrófico. Pombal é das cidades mais ásperas do sertão. Região seca, de homens secos. Muito menino, eu olhava pela fresta da janela a chegada dos cangaceiros.” (Celso Furtado) ${ }^{1}$.

...Sertão. Sabe o senhor: sertão é onde o pensamento da gente se forma mais forte do que o poder do lugar. Viver é muito perigoso... (Guimarães Rosa, 2006, p. 313).

1. Centro Celso Furtado. Disponível em www.centrocelsofurtado.org.br Acesso em: 06/07/2019. 


\section{Introdução}

Celso Furtado investiu bastante esforço pessoal para a criação de um conhecimento técnico e político capaz de promover o desenvolvimento do Nordeste e do Brasil, tomando como ponto de partida a crítica das estruturas arcaicas e antissociais que são a causa do nosso estado de subdesenvolvimento: as oligarquias, os coronéis, a desigualdade regional e à exclusão e exploração do mais pobre. Ele não elaborou isso na Sorbonne ou em outro lugar de sua rigorosa formação acadêmica. Tal ímpeto patriótico a que me refiro teve origem na infância, quando viu, ele mesmo, a seca, os coronéis, a violência, beatos e cangaceiros, a miséria do povo, enfim. De Pombal a Paris e de volta ao Brasil, Furtado vivenciou muitas experiências, mas, os primeiros anos de sua vida lhe imprimiram imagens na memória profunda que o tempo não apagou. Como se o Nordeste fosse um eterno retorno, sempre a ser combatido, superado, melhorado.

É uma espécie de si mesmo em retrospectiva, na relação permanente entre o "eu” e o coletivo, tal como Elias (1994) entende o processo de sociabilidade. Nestes termos, o modo como a criança pequena atribui significado às relações que estabelece com outras pessoas e, mais ainda, como essa mesma criança cresce e vai envelhecendo, define muito a complexidade do ser relacional construído por cada um. Assim, de alguma forma, na linha de raciocínio de Elias (1994), o adulto traz consigo aquela criança que, outrora, foi se co-

2. O título deste artigo remete à obra de João Cabral de Melo Neto. O enfoque deste artigo não diz respeito a reflexões sobre educação a partir de Celso Furtado. Busca-se enfatizar como o mesmo teve, a partir de sua vida de criança no Sertão da Paraíba, todo um conjunto de experiências que o marcaram para sempre, tal qual dita por João Cabral, uma educação pela pedra, entranhada, quer dizer, insubstituível, marcante, cujos impactos são decisivos para toda a sua trajetória, seja como pensador, seja como político. O Nordeste sempre marcou a vida de Furtado, foi-lhe entranhado. 
zendo a fogo frio no forno próprio das relações entre indivíduo e sociedade.

Neste texto, pretendo explorar aqueles que considero serem os temas recorrentes na vida de Furtado: a crítica do subdesenvolvimento, a luta contra as oligarquias nordestinas e a criação da SUDENE (Superintendência do Desenvolvimento do Nordeste) como expectativa de transformação de estruturas. Assim, proponho-me a um exercício modesto para pensar sobre o que ele chamou, em sua obra autobiográfica, de Fantasia Organizada e A Fantasia Desfeita. De maneira resumida, em concordância com João Cabral de Melo Neto, identifico em Furtado a criança que teve uma educação pela pedra: entranhada.

Partindo do ponto de vista de que a história do indivíduo é a história de suas relações, o contexto histórico brasileiro do pós-Segunda Guerra até o governo de Juscelino Kubistchek (JK) foi responsável por feitos de largas proporções no país inteiro (construção de Brasília, industrialização, SUDENE etc.), tendo a participação de grandes nomes políticos, intelectuais, movimentos sociais e do povo, em uma efervescência e entusiasmo para elevar o país a outro nível de desenvolvimento. Assim, Furtado faz parte de um grande time, de um contexto que tentou construir algo novo, embora suas contradições tenham contribuído para o golpe militar de 1964 (FURTADO, 1997a).

Celso Furtado, na Operação Nordeste, analisou o contexto social próprio do período JK, no qual, segundo a presença de lideranças importantes favoreceu a realização de tantas conquistas. No caso do Nordeste, a tarefa de criar uma política desenvolvimentista e democrática, baseada na industrialização, na racionalidade política e no planejamento estratégico, em afronta direta às estruturas políticas da Velha República, só se tornou possível em virtude de um cenário político que ocorre no Brasil em descompassados soluços. 
O acerto de contas do menino de Pombal com aquele lugar de coronéis, beatos e cangaceiros, ocorreu como diz a música: "Na memória de criança um desejo de menino"3 . Na verdade, o próprio Furtado se tornou uma espécie de Lampião, contra os coronéis. Porém, sem fuzil e sem cartucheira, mas com as armas da argumentação democrática e da inteligência aguda do economista universal.

O que se viu foi um contexto de trajetórias coletivas. Em outras palavras, Juscelino Kubitschek, Victor Nunes Leal, Celso Furtado e Dom Hélder Câmara, para citar só estes, estão para o Nordeste dos anos de 1950, o que Zico, Sócrates, Falcão e Cereso foram para a Seleção Brasileira na Copa de 1982. Na mesma correspondência e reciprocidade, o presidente Juscelino motivou o país, com o entusiasmo próprio do talentoso Zico, tabelando em todas as posições, a liderar o time e fazer gol. Era ele mesmo e Telê Santana em um só corpo, ao lado do Dr. Sócrates, com seus calcanhares sutis e canhão no chute, tal como Victor Nunes Leal, a esclarecer e avançar na luta contra o coronelismo que, até então, simbolizava a chave da verticalização política a reproduzir desigualdades. Junto aos dois, Celso Furtado, o Falcão, com elegância e racionalidade brilhantes, jogando esguio, peito pra frente e queixo levantado, igual a sanfoneiro bom, que não baixa a cabeça. Para completar o quarteto fantástico, o caipira, o volante, o que carregava o piano e que, ao se olhar, parecia o menor entre as estrelas, mas que se agigantava em seu ofício. Sim, desse jeito era Cereso e também Dom Hélder Câmara, dois titãs sertanejos, incansáveis na caminhada. Para engrossar o caldo, como se diz no popular, os papéis se invertiam e Zico virava Cereso que parecia com Falcão que incorporava Sócrates, que fazia o gol. Para o expectador, de tão sintonizados, eram quatro em um, ou, um mesmo nos quatro.

3. Zé Ramalho. “Cavalos do Cão”. 
Tendo Juscelino à frente, aquele time parecia imbatível, com o país em pleno vapor de expectativas para sair do atraso, em desenvolvimento. Com Zico, a Seleção, finalmente, seria campeã do mundo de novo, ainda mais no momento da redemocratização, da retomada da esperança, do fim nebuloso da Ditadura. A questão, lamentável, é que no meio do caminho tinha um Paulo Rossi, tinha um Paulo Rossi no meio do caminho ${ }^{4}$. Em resumo, tanto mais pra lá, quanto mais pra cá, o sobrenatural de Almeida ${ }^{5}$ agiu e, o que parecia vitória certa, transformou-se em fantasia desfeita (FURTADO, 1997a).

\section{Um país de coronéis}

A criação da Guarda Nacional (1831) em substituição às milícias e ordenanças definiu a patente de Coronel para o comando municipal ou regional e deu início ao que ficou conhecido por coronelismo. Tal patente, reconhecida pela Regência, agregou em torno de si muito prestígio político e ampliou, ainda mais, a estrutura hierárquica própria de uma sociedade estratificada segundo bases escravagistas. Essa estrutura, circunscrita no município, consolidou verdadeiros potentados rurais em todo o país, cujo desdobramento definiu a nossa estrutura partidária derivada da politicagem local e comandada pelos coronéis. (LEAL, 2012).

Como toda relação de poder, não se tratava de puro mandonismo, ou imposição monocrática de um todo poderoso local sobre seus subalternos. Mas de interação, adaptação, de hierarquias renovadas por favores, acordos e negociações. Em resumo, o coronelismo consiste em uma espécie de troca de proveitos entre o poder público (municipal, estadual e federal) e as bases eleitorais comandadas por esses

4. Carlos Drummond de Andrade, No meio de caminho. Poema

5. Personagem de Nelson Rodrigues. 
líderes. De modo detido, falar em coronelismo é o mesmo que em mundo rural, cuja abrangência, até bem pouco tempo, pelo menos até a década de 1970, era a majoritária massa eleitoral brasileira.

Por conta do vínculo com a propriedade rural latifundiária, passouse a denominar de voto de cabresto os eleitores controlados pelos coronéis. Eram pessoas residentes em suas terras (moradores), que dependiam do proprietário para tudo, tendo em vista a situação de miséria em que a maioria se encontrava. O coronel, por assim dizer, resumia em sua pessoa todo o complexo institucional (saúde, educação, polícia, trabalho), assumindo jurisprudência sobre uma base eleitoral no município que, a partir de acordos e conchavos, influenciava diretamente para a definição dos cargos municipais (prefeito e vereadores), estaduais (governador, senadores e deputados) e, também no plano federal (presidente).

Em muitos casos, o fazendeiro era um rico de fachada. A situação de miséria em que se encontrava o trabalhador rural fazia com que $o$ dono da propriedade, com casa grande, automóvel, gado e influência política o assemelhasse, de fato, a um homem muito rico. No entanto, a realidade era outra. Muitos endividados, com as terras hipotecadas e dependentes dos financiamentos dos bancos estatais. Em outras palavras, não era incomum identificar nos coronéis uma espécie de aristocrata falido, pois tinham terras e negócios, mas sem disponibilidade financeira, buscando condescendência fiscal e sempre ávidos por mais empréstimos e favores de bancos públicos para suas atividades, tendo no povo de sua jurisdição, o capital político para afiançar essas articulações lucrativas. Ricos em comparação aos miseráveis.

O trabalhador rural, no contexto histórico descrito por Leal (2012), era completamente analfabeto, sem acesso à assistência médica ou quaisquer meios de informação (quando muito um rádio). De certa 
forma, a única ligação que tinha com o mundo “exterior” se dava através do coronel, que lhe atendia em "socorro", nas dificuldades. Por isso, sempre foi indispensável para esses líderes locais controlarem as instituições. Da parte do pobre, seu horizonte se restringia a uma luta com o coronel e pelo coronel como forma de proteção para suas “obscuras existências” (LEAL, 2012, p. 47).

Não é demais lembrar que a estrutura do coronelismo estava baseada na concentração fundiária, como forma, inclusive, de garantir seu domínio sobre as populações que residem em suas terras. Do ponto de vista da exploração econômica, baseava-se na atividade agropecuária extensiva e predatória, a intensificar a depreciação do solo, o desmatamento e a desertificação, no caso particular do semiárido nordestino. Na verdade, o que garantia a reprodução da estrutura dominante não era a atividade econômica em si, mas à miséria da população rural que, no "voto de cabresto", garantia as articulações entre os coronéis e os políticos em escala crescente a partir dele. Assim, formava-se um círculo vicioso, a começar no município, baseado na exploração da miséria da maioria, cujo resultado era a garantia de privilégios, empréstimos, construção de barragens, estradas e cargos públicos como pagamento aos coronéis pelo seu "tesouro eleitoral”.

O coronel possuía um "espírito público”, no sentido de buscar por melhorias para seu município e, portanto, ao auxílio das pessoas de sua jurisdição municipal. Enfrentar tal círculo vicioso era de fundamental importância para que o país rompesse com as estruturas do atraso e do subdesenvolvimento. Victor Nunes Leal analisa a questão do desenvolvimento como resultante de um problema político ${ }^{6}$. Assim, a construção de um projeto de país teria, necessariamente, de

6. Uma importante discussão sobre a questão do desenvolvimento regional como problema político pode ser encontrado em outro clássico. Ver Carvalho (2012). 
passar por uma revisão do quadro político vigente. O problema não se limitava à falta de conhecimento técnico e de recursos, mas, a própria engenharia política impedia mudanças significativas para a solução dos graves problemas nacionais e do Nordeste. Celso Furtado conhecia de perto tais estruturas anacrônicas e, do mesmo modo, tinha consciência do enorme esforço político para enfrentá-las.

\section{Celso Furtado - Operação Nordeste}

O clima político vivido no Brasil, da década de 1950, era de grande efervescência, um despertar de confiança, principalmente por conta da construção de Brasília, quando Juscelino inspirava o país para a possibilidade de, na nova Capital da República, as nossas instituições políticas serem renovadas, com ares revigorados para enfrentar o futuro. Em várias passagens Furtado (1997) destaca a personalidade fascinante de JK. Esse espírito apaixonado e patriótico do presidente "contaminou" Furtado sobre o Nordeste. Foram ambos, em escalas diferentes, Dom Quixotes desbravadores dos sertões. Mesmo contido em sua racionalidade de economista, Furtado alçou velas nos ventos alucinantes de Juscelino.

Não era uma década de entusiasmos e facilidades, apenas, havia muita resistência e sabotagens. De certo modo, as conquistas do período JK foram bastante significativas, mesmo acompanhadas de contradições e desequilíbrios macroeconômicos. Na análise de Furtado, serviram em larga medida como justificativa para o golpe militar de 1964. A classe média, com sua pauta conservadora, mostrou-se bastante descontente com o período de esfriamento econômico e de inflação que o seguiu. No Nordeste, a seca de 1958 agravou o quadro de calamidade pública, ampliando a fome como problema estrutural. 
Neste âmbito os camponeses nordestinos (Paraíba e Pernambuco) se mobilizaram em defesa de direitos mínimos, semelhantes aos que já haviam sido conquistados pelos trabalhadores urbanos da indústria (ARAÚJO, 2019). Mais do que nunca, o Nordeste se revelou como o grande problema nacional. E a Igreja Católica, liderada por Dom Helder Câmara, aproximou-se dos movimentos sociais, consolidandose, ao contrário do que a Igreja tradicional até então fizera, em forte espaço de formação e resistência contra a flagrante perpetuação de disfarçadas relações escravagistas.

Furtado cita o Relatório Ramagem ${ }^{7}$, cuja maior preocupação era a garantia da ordem social, tendo em vista, na visão militar, a malversação dos recursos públicos e a urgente intervenção federal, com a necessária nomeação de militares à frente de órgãos estratégicos, incluindo a substituição de governadores. $\mathrm{O}$ que os militares queriam era "fincar pé” no Nordeste, criando para si uma base política que, no limite, seria oposição ao próprio Juscelino. Seguindo tais orientações, o presidente estaria, literalmente, criando cobras que lhe depositariam fortes cargas de veneno em pouco tempo.

Nesse cenário, alguém citou para o presidente o nome de Furtado, que, naquele momento, havia assumido uma diretoria no Banco Nacional de Desenvolvimento Econômico (BNDE), com dedicação ao Nordeste. $\mathrm{O}$ enorme esforço seria convencer o presidente de que o problema da região não estaria em ampliar as frentes de emergência, construir mais açudes ou ações do tipo. Tais iniciativas, há décadas, eram realizadas, a chamada "solução hidráulica”, mas sem resultados concretos. Existiam questões estruturais a serem atacadas, tendo em vista que o fenômeno da estiagem no semiárido era cíclico e que as elites locais, ao contrário do que se pensava, não perdiam com ela,

7. Juscelino enviou ao Nordeste o Coronel Ramagem, que deu nome ao Relatório. 
mas se beneficiavam muito, seja política, seja economicamente, com o que ficou conhecido como indústria da seca ${ }^{8}$. Os oligarcas latifundiários e comerciantes, em tempos de seca, tinham seus negócios potencializados pela alta dos preços, pelos auxílios governamentais e, principalmente, ao controle da população miserável, que se tornava capital eleitoral para os projetos políticos dos coronéis.

Assim, convencido o presidente de seus argumentos, Furtado foi integrado ao GTDN (Grupo de Trabalho para o Desenvolvimento do Nordeste), liderado por Aluísio Campos, um político e advogado paraibano brilhante, mas com pouca ou nenhuma formação especializada sobre desenvolvimento. Na verdade, o grupo era composto por pessoas sem o perfil para pensar a região como um todo. Havia, assim, um olhar particularizado sobre problemas setoriais, faltava a visão macroeconômica que conduziria o Nordeste de "região problema" a potencial indutor do desenvolvimento do país. Coube a Furtado o papel de pensador e regente da "Fantasia Organizada”, quer dizer, na condução dos meios racionais e burocráticos para transformar o entusiasmo de Juscelino e de tantos, inclusive do próprio Furtado, em política objetiva de transformação social.

Com o GTDN e seus desdobramentos até a SUDENE, Furtado consolida um campo de estudo no Brasil: o desenvolvimento regional. Significa dizer que, de modo simultâneo, conhecimento acadêmico especializado (economia) por um lado, mais a capacidade de articulação política resultaram em algo novo, cujo objetivo seria o planejamento regional baseado na crítica das estruturas socieconômicas, não na ecologia, na seca. Furtado muda o foco, no sentido de desnaturalizar o problema. Em poucas palavras, afirma que o problema estaria

8. Expressão criada por Antônio Callado. Para ele, os “industriais da seca” dominavam a região e tinha larga força e prestígio no Congresso Nacional. 
no campo da cultura, não da natureza. Essa antropologização do problema trouxe à tona os verdadeiros atores: os coronéis e políticos (de vereadores a governadores e senadores) que se beneficiavam da miséria de homens e mulheres nordestinos. Quanto mais seca, mais latifúndio, miséria, concentração de renda, terra e voto de cabresto. Celso Furtado e Victor Nunes Leal tabelam bem na cabeça da área dos coronéis, que passaram a sentir calafrios na espinha, tal como ocorrera quando da chegada de Lampião ou Antônio Silvino no oitão da casa sede da fazenda.

Os esforços foram destinados à construção de um documento técnico sobre a região subdesenvolvida, diagnosticando a problemática regional e que pudesse ser a nova política estratégica para o desenvolvimento do Nordeste, objetivando integrá-lo economicamente ao Centro Sul do país, de economia mais dinâmica. Em resumo, falar em desenvolvimento regional, na percepção de Furtado, diz respeito a: integração nacional, planejamento, interior como potencial econômico, combate às estruturas arcaicas/subdesenvolvidas (oligarquias) e soberania. Enquanto os militares e a classe média queriam intervenção e combate à corrupção ${ }^{9}$ e as oligarquias a preservação das estruturas da Velha República, Furtado apresenta um conteúdo novo, que avançou em relação ao demagógico e localizado, que se propôs, assim, a pensar o todo regional e a integrá-lo ao país, no entendimento de que não haveria desenvolvimento para o Brasil se o Nordeste continuasse como zona de miséria. A “Operação Nordeste” seria, no fim, a própria redenção do país para outro patamar civilizatório.

O ponto de partida para tamanha realização necessitava da opção por um capitalismo produtivo, gerador de emprego, principalmente

9. Estamos falando da década de 1950, não de hoje. A semelhança não é mera coincidência. 
na indústria e na produção de alimentos, não no especulativo, baseado no endividamento e na dependência externa. Assim, indústria e alimentos seriam o caminho para criar, tanto no meio rural, quanto no urbano, pessoas alimentadas, educadas e com renda suficiente para se livrarem das garras dos coronéis. A expansão da fronteira agrícola pra o Maranhão se colocou como alternativa viável, pois resolveria a tensão dos conflitos por terra.

Com a indústria, haveria a possibilidade de novos investimentos e na indução de empresários inovadores, na perspectiva schumpeteriana, capazes de criar um ambiente de negócios mais próximo da moderna economia capitalista, principalmente na ampliação e fortalecimento do mercado interno. Em síntese, desenvolvimento regional dizia respeito, no limite, a um projeto de democratização e empoderamento. Aí estava o sonho de Furtado para o Nordeste e para o Brasil.

A luta inglória a ser enfrentada ocorreu porque o Estado (Federal) era domesticado pelos interesses particulares, sendo o Congresso, o celeiro das oligarquias regionais ${ }^{10}$. A novidade que a nova proposta institucional trazia era o distanciamento entre os esquemas arcaicos e tradicionais de "enfeudização", nos termos de Furtado. Portanto, libertar os recursos federais das garras dos coronéis e da politicagem era o maior problema.

A criação da SUDENE, como Superintendência diretamente ligada à presidência da República, seria uma novidade política no modelo federativo brasileiro, tendo em vista que, na prática, colocou-se entre a federação e os estados, como poder regional articulado, democraticamente organizado, com a participação de governadores, bancos estatais, representações da sociedade civil etc. Sua criação teve passo político importante a partir do Conselho de Desenvolvimento

10. Qualquer semelhança com a atualidade não é mera coincidências. 
do Nordeste (CODENO), de 25 de abril de 1959 e a fundação em 15 de dezembro de 1959, com a Lei 3.692.

A maior oposição ao projeto veio do próprio Nordeste, tendo no senador paraibano Argemiro de Figueiredo seu principal porta-voz. Como representante das oligarquias, nos termos de Furtado, o citado político organizou uma verdadeira cruzada contra a SUDENE, afirmando ser a mesma um projeto comunista. Furtado foi buscar apoio político em outros estados, do Sul e Sudeste, na justificativa de que a Superintendência seria o caminho mais racional e viável para o Nordeste superar sua contínua dependência em relação ao restante do país. Tal argumentação estratégica, mesmo questionável, pois se apoiava em uma visão preconceituosa, foi adotada por Furtado para que o apoio viesse no Congresso, e deu certo. Assim, com a imensa capacidade política, aliada ao entusiasmo e apoio de Juscelino, Furtado consegue emplacar a SUDENE.

Porém, um outro ator social teve semelhante importância para a dinâmica conjuntural vivida no Nordeste naquele momento. Refiro-me à Igreja Católica e, em particular, ao seu mais eminente líder, Dom Helder Câmara. A participação dos Bispos do Nordeste no cenário político brasileiro é uma história que merece dedicada atenção. De certo modo, a própria preocupação de Juscelino com o Nordeste seria, em larga medida, provocada pela mobilização social que a Igreja fez na região. Os encontros dos Bispos ${ }^{11}$ em Campina Grande (1956) e em Natal (1959) sinalizaram para o presidente a criação de um suporte político com a Igreja, fundamental para um governo com graves dificuldades em relação à opinião pública e, especialmente, com os setores mais tradicionais da política brasileira (elites, militares e classe média).

11. Ver Encontro dos Bispos (2012). 


\section{O papel político da Igreja Católica: entre messiânicos e orgânicos}

O coronelismo municipal estava estruturado em todo o país, muito em função da realidade rural que o caracterizava de norte a sul (LEAL, 2012). No Nordeste, pode-se dizer que assumia contornos mais requintados por causa do fenômeno da seca que posicionava a região como problema recorrente, a demandar da União socorros financeiros aos sempre "famintos" (políticos e flagelados). Historicamente, a Igreja Católica que, segundo o IBGE, até o final da década de 1960 tinha um rebanho de mais de $90 \%$ da população, realizou ações muito pautadas no princípio da caridade, sem, contudo, problematizar as estruturas políticas, estando, por vezes, integrando-as. À exceção de casos pontuais ou iniciativas no plano individual, a relação entre Igreja e Sociedade esteve comprometida com a manutenção dos status quo.

Em outra ocasião (BARBOSA, 2019), analisei essa conjuntura, destacando a importância da Igreja Católica como ator social no Nordeste, mais ainda, como a mesma esteve presente no processo de formação da região e do país. Do ponto de vista sociológico, quer dizer, à busca de objetividade classificatória, identifiquei que, na década de 1950, houve uma inflexão impactante entre Igreja e Sociedade. Até então, o comum era a presença de líderes messiânicos, com destaque para o sertão: Antônio Conselheiro, Padre Cícero, beatos, beatas, rezadeiras, curandeiros. O campo do sagrado estava "delimitado” ao que pode ser chamado de "catolicismo popular", muito definido sincreticamente, pelas tradições religiosas africanas e, principalmente, indígenas, no interior. No entanto, a partir de Dom Helder Câmara, constata-se uma mudança no fazer Igreja.

Os líderes religiosos anteriormente citados: Antônio Conselheiro 
e Padre Cícero, assim como Dom Hélder e Padre Ibiapina eram todos cearenses. Na verdade, ao estudar a história do último, Padre Ibiapina, algumas realizações suas saltam à vista. Foi um jurista e político influente em Recife que abandonou a vida na capital pernambucana e desbravou o interior nordestino no lombo de jumento, promovendo as suas missões. Em cada localidade onde chegava, simultânea às preces e orações que atraíam milhares de pessoas, construiu açudes e várias Casas de Caridade, onde eram abrigados órfãos, ensinava-se a ler e a escrever, além de promover formas de profissionalização, principalmente para as mulheres.

O padre Ibiapina, a partir de 1860, inaugurou novas possibilidades de convivência e de sociabilidade no campo religioso. Não era só a edificação comunitária de prédios, mas uma missão pastoral de transformação, em um lugar onde inexistia qualquer tipo de atuação estatal para serviços de educação e saúde, por exemplo.

A opção pelos pobres que seria amplamente discutida no Concílio Vaticano II, na década de 1960, quer dizer, cem anos depois, Ibiapina havia iniciado a partir de sua terra natal, sertão cearense, até o agreste paraibano. Assim, influenciou decisivamente na formação dos conterrâneos que vieram depois dele: Antônio Conselheiro, Padre Cícero e também Dom Hélder, todos, uma espécie de discípulos pastorais de Ibiapina.

A história de Canudos só pode ser mais bem entendida com a devida compreensão dessa postura missionária e de mobilização popular para o combate dos problemas sociais. O massacre, o genocídio de Canudos, representou a força das elites sobre o Brasil profundo, sobre o pobre que se organizou contra a fome e a exploração (CUNHA, 2002). Com o mesmo ímpeto para a organização social, Padre Cícero construiu um verdadeiro Forte (econômico e religioso) onde antes era 
apenas modesto vilarejo. O excelente livro de Lira Neto (2009) sobre o "Padim Ciço do Juazeiro" esclarece o quanto a Igreja Católica, no que tinha de concordância e conflitos internos, mobilizou forças e atuou como protagonista social. Diferente de Antônio Conselheiro, Padre Cícero era líder religioso, político (deputado, vice-governador, prefeito), dono de terras, gado, engenho, força militar, respeitado por cangaceiros (Lampião) e tudo o mais de espetacular que um coronel poderia ter sobre si. Ambos, marcadamente detentores de posturas messiânicas (Conselheiro: “o sertão vai virar mar”; crítica à modernidade/República. Pe. Cícero: “parte da Santíssima Trindade”, milagre do sangue na boca da beata), arrebanharam milhares de fiéis nos sertões nordestinos e promoveram verdadeiros levantes revolucionários, seja ao enfrentamento conflituoso, seja à coesão social.

Dom Hélder, por outro lado, liderou uma Igreja do messias (Jesus Cristo), mas em outra perspectiva política e espiritual. Lutar contra a miséria era o verdadeiro papel do cristão e caberia à Igreja a opção pelos pobres. Fé e política caminhando juntas para a promoção da justiça social. O termo "orgânico", aqui utilizado, aproxima-se mais do conceito de solidariedade de Durkheim, do que do gramsciano. Assim, refere-se à capacidade de criar bases solidárias e políticas que promovam a ordem social através de instituições interdependentes, gerando coesão social. Não é, nestes termos, a Igreja, revolucionária, mas preocupada com a mudança social através de mecanismos democráticos e coordenados por um ordenamento jurídico e político comprometido com a redução das desigualdades sociais. De messiânica, passa a ser “orgânica ${ }^{12 ”}$. A mudança foi radical ao se aproximar e unir forças às

12. Orgânico, aqui, possui o sentido atribuído por Durkheim, nem tanto por Gramsci. Significa solidariedade no contexto moderno de ampliação das relações de trabalho na indústria e no contexto urbano, assim como o aumento do fenômeno do individualismo. A Igreja de Dom Hélder não era revolucionária em termos so- 
ideias de Furtado sobre o Nordeste. Em outras palavras, Dom Hélder pode ser visto como um Celso Furtado de batina, até porque o que se construiu como teologia da libertação era a versão religiosa da crítica ao subdesenvolvimento, tão teorizada e discutida por Furtado.

\section{Furtado: da catarse sociológica ao teórico do subdesenvolvimento}

A vida intelectual de Furtado foi marcada por profunda coerência, tanto em relação às ideias, quanto aos valores. Seja no BNDE (anos 1950), seja no Ministério da Cultura do Governo Sarney (anos 1980), pode-se identificar nas obras e nas ações uma postura cívica e intelectual sem máculas ou desvios. Nessa trajetória, a definição de fases é importante ao entendimento de uma vida fértil intelectualmente e ativa no campo político.

Assim, do ponto de vista didático, alguns momentos importantes da vida de Furtado merecem destaque. Inicialmente, o que chamo de catarse sociológica, período da infância em Pombal e em João Pessoa, quando viveu a realidade dura do sertão na plenitude de suas contradições, a educação pela pedra. Em seguida, os anos de formação, primeiro no Rio de Janeiro, depois, com a participação na II Guerra Mundial e os estudos econômicos em Paris, cujo desdobramento foi o clássico: Formação Econômica do Brasil (FURTADO, 2002). Depois, com a volta para o Brasil, após a passagem pelo Chile (CEPAL - Comissão Econômica para a América Latina, órgão das Nações Unidas) tem início outro momento, o do pensador e político, quando atuou

cialistas, mas baseada em valores democráticos, na distribuição de renda, nos direitos (humanos, trabalhistas, em especial), que exigiam reformas estruturais como a agrária. Dom Hélder e seus colegas religiosos estavam preocupados em combater as injustiças sociais, a fome e a miséria que viam em suas Dioceses. 
em vários setores da burocracia nacional, com destaque para a SUDENE e o Ministério do Planejamento no Governo de João Goulart. No exílio, a partir de 1964, no Chile, nos Estados Unidos e em Paris, tem-se início o período de aprofundamento dos estudos sobre o subdesenvolvimento, especialmente como professor da Sorbonne e nos textos que passou a escrever e ganhar notoriedade internacional. Finalmente, com a redemocratização, assume, no governo Sarney, a pasta de Ministro da Cultura, quando realiza um trabalho de peso no tocante aos incentivos e estudos de uma economia da cultura, percebendo-a como a maior riqueza do Brasil e inesgotável potencial econômico. Esta fase, mais antropológica, também coincide com sua efetiva participação nos debates da Constituinte, que resultou na Carta Magna de 1988, cujo empenho esteve dedicado, com maior afinco, à preocupação da redução das desigualdades regionais como princípio constitucional. A partir dos anos de 1990, fase da maturidade, incorpora nas suas preocupações a questão ambiental.

Cada fase destacada possui complexidade para várias pesquisas de teses de doutorado. No entanto, o que procuro evidenciar, neste momento, são dois pontos que considero fundantes do próprio Furtado: a educação pela pedra e a construção, no Brasil, de uma área de pensamento denominada de Desenvolvimento Regional. A primeira fase já teve sua cobertura. $\mathrm{O}$ que pretendo explorar um pouco é esse segundo enfoque.

Com a Operação Nordeste, o GTDN, a SUDENE e o Ministério do Planejamento, algo novo surge. Não se trata do economista ou o trabalho de mais um tecnocrata. Furtado assume três ações ao mesmo tempo, o que lhe define a interdisciplinaridade como marco importante. Ele foi, no pensador e político regional: teórico (não só economista, mas leitor do país, com análises conjunturais atualizadas e sis- 
temáticas pelo rigor científico); político (homem de ação, com capacidade de articular setores da política, da sociedade civil, da Igreja e do setor econômico) e, por fim, identificado culturalmente com a região (o Nordeste não era e nunca foi um objeto de análise ou laboratório para aplicação de programas ou modelos a serem avaliadas as efetividades com dados estatísticos frios, o Nordeste fora e continuou sendo por toda a vida, seu lugar de origem, presente nas ideias, nos valores, no sotaque que nunca perdeu). Assim, criou uma área ou abordagem de conhecimento, o desenvolvimento regional. A partir de Furtado, quem se propõe a enveredar por essa área não pode ser o intelectual de gabinete ou o ativista panfletário, mas uma espécie de pensador e homem de ação, apaixonado pela região de origem, entendendo-a no plano mais amplo de sua relação com o país. O desenvolvimento regional não se limita a questões ou projetos particulares, ele diz respeito a integração, a redes e articulações que só fazem sentido no plano de conjunturas escalares amplas, em sintonia com os princípios da soberania e da integração nacional.

Assim, o Desenvolvimento Regional é comunitário quanto a origem e identidade, e nacional quanto à integração, seu limite é antropológico, circunscrito pela relação de aproximação e diferenciação com outras regiões. Furtado fez isto ao problematizar o Nordeste, construindo as bases para se pensar o país como um todo. Em resumo, só faz sentido no plano macro, articulado com outras regiões que compõem e integram o país, apreendido e vivido para quem teve uma educação pela pedra, entranhada. 


\section{Conclusão}

Para o prazer e para ser feliz, é que é preciso a gente saber tudo, formar a alma, na consciência; para penar, não se carece: bicho tem dor, e sofre sem saber mais porque. (Guimarães Rosa, 2006, p. 313).

Todo o esforço empreendido a partir do governo JK e que continuou no Ministério do Planejamento de João Goulart esteve focado na tentativa de colocar o Brasil na rota do capitalismo moderno, tal como estava sendo implantado e consolidado na Europa Ocidental no pós-Segunda Guerra. Em resumo, tinha na orientação keynesiana a expansão da produção industrial em massa e da ampliação da classe trabalhadora formal que demandaria por um consumo ampliado e o consequente fortalecimento do mercado interno pela renda promovida pela industrialização. Além disso, no campo, ao contrário de teimar nas monoculturas latifundiárias, extensivas e predatórias, deveria o país estimular a produção de alimentos e a modernização das tecnologias ao racional uso das reservas naturais. Assim, o que antecedeu ao golpe de 1964 foi, por parte de Furtado, a elaboração de uma teoria/ação de um modelo de desenvolvimento.

O que ocorreu com o Brasil a partir dos militares veio a se confirmar como uma modernização conservadora, por seguir a cartilha americana para a América Latina, naquilo que consiste na dependência, industrialização periférica e exportador de matérias-primas (agora, commodities). Furtado, no exílio, com o Mito do desenvolvimento econômico (FURTADO, 1996), amplia ainda mais seu campo de análise e radicaliza a crítica teórica sobre um modelo de desenvolvimento que possui sofisticadas capacidades de enriquecimento, ao passo que concentra renda, intensifica a exclusão social e degrada o meio ambiente. O Brasil seria isto, potência econômica habitada por milhões de 
miseráveis, tendo suas elites preocupadas em reproduzir o consumo dos países centrais, ao passo que a maioria da população continua privada do mínimo para a sobrevivência e com seus biomas ameaçados (amazônia, pantanal, caatinga, cerrado, mata atlântica, pampa). Nosso problema seria este: a acumulação desigual que intensifica as contradições e amplia as desigualdades regionais, uma vez que a geração da riqueza se concentrou, em maior escala, em São Paulo.

A “Operação Nordeste", naquilo que furtado chamou de "Fantasia Organizada”, deve ser vista como uma tentativa de interiorizar o desenvolvimento para além dos centros urbanos tradicionais. Com a construção de Brasília e a SUDENE, Juscelino Kubitschek avançou para os sertões, na esperança de, neles, redescobrir o Brasil. Tal entusiasmo trouxe para perto de sua causa grandes nomes, que, aqui, eu destaquei Celso Furtado, Dom Hélder Câmara e Victor Nunes Leal, mas que poderia citar outras dezenas. A questão central a ser explorada diz respeito ao fato de que o Brasil não sabe conviver muito com a combinação entre democracia, desenvolvimento e interiorização/integração. Nossa história parece estar mais próxima das expedições e bandeiras antropofágicas a dominar e subjugar as tribos do interior.

As tentativas de interiorizar o desenvolvimento por vias democráticas foram seguidas de Golpes. Foi assim com Getúlio. Como ditador modernizou e desenvolveu, mas, como eleito democraticamente, não conseguiu se manter e acabou se matando. Com Juscelino, aos troncos e barrancos terminou o mandato. João Goulart, por outro lado, não terminou o mandato como se sabe (golpe de 1964) e a experiência dos governos do PT está aí para demonstrar que o império sempre contra-ataca para a recomposição da hegemonia.

Vivemos hoje exatamente isto, no melhor estilo de Guerra nas Estrelas, o contra-ataque do império a reposicionar o país que, de certo 
modo, fugiu do seu controle a partir da Constituição de 1988. O que vivemos não é uma luta contra o PT, mas contra a Constituição, que teve, a partir dos movimentos populares pós-ditadura, a efervescência social para formalizar no país as bases de uma socialdemocracia e a redução de desigualdades.

Portanto, não se trata de luta entre esquerda e direita, entre capitalismo e socialismo. Mas entre o Brasil do coronelismo que se renova (Bíblia, bala, boi etc.) e outro, profundo, popular, periférico, diverso, que teima hoje, como sempre, em não aceitar a condição de vira-lata.

A sensação que tenho é a de que estamos naquele momento dos anos de 1970, de nebulosas expectativas. Celso Furtado e seus contemporâneos não são apenas atuais, mas necessários para hoje. São proféticos, utópicos, no sentido de portarem a esperança no lugar da desesperança e da desilusão, que é a dança da solidão, como nos diz Paulinho da Viola.

Para lembrar Frei Beto, “deixemos a desesperança para dias melhores”. O momento agora é o de avaliação, proposição, de ver, julgar e agir, na esperança renovada de jogarmos de novo um bolão, como aquele de Zico, Sócrates, Falcão e Cereso.

No caso de Furtado, inspirar-se nele naquilo que lhe era farto, o amor incondicional pelo Nordeste, pelo Brasil, próprio de quem teve uma educação pela pedra.

... Outra educação pela pedra: no Sertão (de dentro para fora, e pré-didática). No Sertão a pedra não sabe lecionar, E se lecionasse, não ensinaria nada;

Lá não se aprende a pedra: lá a pedra, Uma pedra de nascença, entranha a alma. (João Cabral de Melo Neto). 


\section{Referências}

ARAÚJO, Ana Paula Balbino de. A importância das Ligas Camponesas no Currículo Escolar na Escola Estadual de Ensino Fundamental Boa Vista (Sapé-PB). Disponível em: repositorio.ufpb.br. Acesso em: 20/07/2019.

BARBOSA, José Luciano Albino. Das provocações cearenses ao pós-secular: reflexões sobre Igreja e Sociedade no Nordeste Brasileiro. Disponível em: www.unicap.br. Acesso em: 01/06/2019.

CUNHA, Euclides da. Os Sertões: campanha de Canudos. 4a Edição. São Paulo: Editora Martin Claret Ltda, 2002.

ELIAS, Norbert. A sociedade dos indivíduos. Rio de Janeiro: Jorge Zahar Ed., 1994.

CARVALHO, Otamar. Desenvolvimento Regional: um problema político. Campina Grande: EDUEPB, 2012.

CENTRO CELSO FURTADO. Disponível em www.centrocelsofurtado.org.br. Acesso em: 06/07/2019.

COLOMBO, Luciléia Aparecida. A Sudene no sistema federativo brasileiro: ascensão e queda de uma instituição. Recife: Superintendência do Desenvolvimento do Nordeste, 2015.

ENCONTRO DOS BISPOS. Campina Grande: Editora Universidade Estadual da Paraíba, 2012.

FURTADO, Celso. Teoria e Política do Desenvolvimento Econômico. $4^{\mathrm{a}}$ Edição. São Paulo: Editora Nacional, 1971.

. A Nova Dependência: dívida externa e monetarismo. Rio de Janeiro: Paz e Terra, 1982a.

. O Brasil Pós- “Milagre”. 7ª Edição. Rio de Janeiro: Paz e Terra, 1982b (Coleção Estudos brasileiros; vol. 54).

. O Mito do Desenvolvimento Econômico. $3^{\mathrm{a}}$ Edição. Rio de Janeiro: Paz e Terra, 1996.

. Fantasia desfeita. In: Obra Autobiográfica de Celso Furtado. Tomo II. Edição: Rosa Freire d’Aguiar. Rio de Janeiro: Paz e Terra, 1997a.

. Obra Autobiográfica de Celso Furtado. Tomo III. Edição: Rosa 
Freire d’Aguiar. Rio de Janeiro: Paz e Terra, 1997b.

. Formação Econômica do Brasil. 31 $1^{\mathrm{a}}$ Edição. São Paulo: Companhia Editora Nacional, 2002 (Biblioteca Universitária. Série 2, Ciências Sociais; vol. 23).

. Ensaios sobre cultura e o Ministério da Cultura. Org. Rosa Freire d'Aguiar Furtado. Rio de Janeiro: Contraponto/ Centro Internacional Celso Furtado, 2012.

. Essencial Celso Furtado. $1^{\text {a }}$ Edição. São Paulo: Penguin Classics/ Companhia das Letras, 2013.

. Anos de formação 1938 - 1948. Org. Rosa Freire d'Aguiar Furtado. Rio de Janeiro: Contraponto: Centro Internacional Celso Furtado, 2014.

LEAL, Victor Nunes. Coronelismo, enxada e voto: o município e o regime representativo no Brasil. $7^{\text {a }}$ Edição. São Paulo: Companhia das Letras, 2012.

NETO, Lira. Padre Cícero: poder, fé e guerra no sertão. São Paulo: Companhia das Letras, 2009.

ROSA, Guimarães. Grande Sertão: veredas. Rio de Janeiro: Nova Fronteira, 2006. 


\section{Resumo:}

A importância de Celso Furtado para a história brasileira pósSegunda Guerra Mundial tem sido amplamente estudada e reconhecida. O rigor acadêmico, aliado ao esforço incansável em promover uma política voltada ao desenvolvimento regional do Nordeste e do país, deu-lhe notoriedade internacional. Porém, tento evidenciar, neste ensaio, que Furtado teve algo anterior que lhe serviu de motivação primeira. Refiro-me à experiência, ainda quando criança, no sertão paraibano. Algo que lhe imprimiu bem o descrito por João Cabral de Melo Neto: $a$ educação pela pedra, entranhada. Além disso, o contexto social, próprio da década de 1950, instigou no Brasil o desejo de mudança, motivado por Juscelino Kubitschek e personagens como Dom Hélder Câmara e Victor Nunes Leal ao combate das estruturas oligárquicas. Assim, busca-se explorar a relação entre indivíduo e sociedade e seus desdobramentos no campo político, evidenciando a importância e atualidade de Furtado.

Palavras-chave: infância; relação indivíduo/sociedade; desenvolvimento; identidade regional. 


\begin{abstract}
:
The importance of Celso Furtado for Brazilian history after World War II has been widely studied and recognized. Academic rigor, coupled with a tireless effort to promote a policy aimed at regional development in the Northeast of Brazil and in the country as a well, gave it international notoriety. However, I try to show in this essay, that Furtado had something earlier that served as his primary motivation. I refer to the experience, even as a child, in the Paraíba countryside. Something that impressed him well as described by the poet João Cabral de Melo Neto: education by stone, ingrained. In addition, the social context, typical of the 1950s, instigated in Brazil the desire for change, motivated by president Juscelino Kubitschek and characters like Archbishop Dom Hélder Câmara and Victor Nunes Leal to fight oligarchic structures. Thus, we seek to explore the relationship between the individual and society and its consequences in the political field, highlighting the importance and relevance of Furtado.
\end{abstract}

Keywords: childhood; individual / society relationship; development; regional identity.

Recebido para publicação em 30/07/2019. Aceito em 05/11/2019. 